\title{
EXCLUSION OF ILLEGALITY OF OFFENSIVE SPEECH GIVEN IN DEFENCE OF A RIGHT OR PROTECTION OF JUSTIFIED INTERESTS
}

\author{
UDC 347.92:343.632
}

\section{Danilo Kostić}

Faculty of Law, University of Niš, Serbia

\begin{abstract}
This scientific article analyzes the basic features and elements of the criminal offense of insult from the theoretical and normative aspect, with specific reference to the analysis of the conditions necessary for the application of the special legal ground for excluding illegality of offensive speech, stipulated in Article 170 (4) of the Criminal Code of the Republic of Serbia. Relying on the critical analysis of national criminal legislation and a brief review of national courts' practice, the author points out to the contradiction of adopted legal standpoints when interpreting the disputed provisions, and emphasizes the importance of ensuring uniform and consistent court practice in this field. Proper and complete consideration of the criminal offense of insult, and especially the ground for excluding the illegality of the taken actions, stipulated in the provisions of Article 170 (4) of the Serbian Criminal Code, calls for precise interpretation of these provisions. Inadequate conduct of judicial bodies entails the possibility of convicting the perpetrator of the criminal offense of insult, even if the requisite conditions prescribed in the positive law have not been satisfied.
\end{abstract}

Key words: insult, normative regulations, presumptions for exclusion of illegality, protection of rights and justified interests, intent to disparage

\section{INTRODUCTION}

The knowledge of substantive content and purpose of legal norms, especially legal institutes, is a necessary prerequisite for the correct interpretation of the law and ensuring legal certainty. It enables the court to determine, with a degree of certainty, all the facts essential for establishing the elements of a criminal act which is the subject matter of criminal proceeding, and ultimately render a lawful court decision, respecting the principle of a fair trial. On the other hand, improper implementation or abuse of legal institutes leads to the abuse of rights.

Received July $22^{\text {th }} 2020 /$ Accepted September $14^{\text {th }} 2020$

Corresponding author: Danilo Kostić, PhD student, Faculty of Law, University of Nis, 11 Trg Kralja Aleksandra, 18000 Niš, Republic of Serbia. E-mail: advokat.kostic@yahoo.com 
The commission of a criminal offence entails establishing criminal liability of the perpetrator, imposing an appropriate criminal sanction and entering a criminal conviction into criminal records. One of the ways of exempting the perpetrator from criminal liability is related to the application of the legal grounds whose presence excludes illegality of undertaken actions. Proper application of the aforesaid legal institute in criminal proceedings requires comprehensive knowledge of the basic provisions on the concept and elements of criminal offence, as well as comprehensive knowledge of the prescribed legal principles and provisions which may serve as legal grounds for decriminalizing certain conduct that comprises all elements of a criminal offence, except from illegality.

The criminal offence of insult is falls within the category of rare criminal offences for which the legislator prescribes a special legal ground for excluding the illegality of undertaken actions. Although the provisions of Article 170 (4) of the Serbian Criminal Code $^{1}$ prescribe the requirements for applying the legal grounds for excluding illegality of offensive conduct, they have not been sufficiently addressed in terms of theoretical explanation and analysis and are thus inapplicable in practice. Given that establishing the (non)existence of the perpetrator's criminal liability for the criminal offence of insult depends on the application of these legal provisions, it is crucial to provide a more detailed theoretical explanation of this legal institute.

\section{CRIMINAL OFFENSE OF INSULT: THEORETICAL ASPECT}

The criminal offense of insult is one of the basic criminal offenses in the group of criminal offenses against honour and reputation. Proper and comprehensive consideration of its basic features (elements of crime) requires a comprehensive approach to the analysis of the protective object (the subject matter and purpose of protection ILI object of protection?), the act of committing the offense, the form of offensive conduct, and the intent of its perpetrator.

In the criminal offense of insult, the subject matter of protection are honour and reputation. These are moral categories of human personality, featuring essentially identical content, considering that both honour and reputation reflect the overall values of a person as a human being and a member of certain social community (Jovanović, Đurđić, Jovašević, 2000: 243). However, the modes of manifestation of human values are different. The normative notion of honour is related to the internal reflection of values in the person him/herself; thus, by its nature, honour represents a personal value that is part of human dignity (Jovašević, 2017: 84). On the other hand, reputation is a social recognition of human values expressed through one's work and behaviour. It is a set of intangible values that a person acquires during his/her life through work and behaviour in society. The definition of reputation entails an external, objectified form of honour, which is reflected in the evaluation of human abilities and characteristics manifested through his/her behaviour (Jovanović, Đurđić, Jovašević, 2000: 243). Regardless of diverse manifestations, reputation and honour are inseparable categories of human values which enjoy the same protection in criminal law.

Theoretically speaking, the act of committing the crime of insult consists of a statement or behaviour that disparages and violates the honour and reputation of another person

${ }^{1}$ Criminal Code, Official Gazette RS, no. 85/2005, 88/2005, 107/2005, 72/2009, 111/2009, 121/2012, 104/2013, $108 / 2014,94 / 2016,35 / 2019$ 
(Jovanović, 1983: 248). The conduct must be of such nature that it underestimates or disrespects the personal qualities, abilities, virtues and values of another person.

Depending on the activity by which the consequence is realized, we can distinguish three forms of insult: 1) verbal insult - an insult by which a person is directly or indirectly disparaged by an oral or written utterance; 2) real insult - behaviour aimed at the body of another person for the purpose of damaging his/her honour and reputation; ${ }^{2}$ and 3) symbolic insult- disparaging another person by using a sign, drawing, gesturing, facial expression, imitation and other similar means. In order for a certain act to have the character of a real and symbolic insult, it is not enough to take actions that are characterized by ordinary rudeness or impoliteness. The criminal act of insult implies extreme cases of indecency, where derogatory character of undertaken actions is clearly and unambiguously expressed (Stojanović, 2012: 505).

In order to be qualified as the criminal act of insult, the disparaging statement has to be communicated to the injured party, directly or by a third party (Ignjatović, 2007: 55), and recognized as such. Whether the statement or behaviour in a specific case will be recognized as offensive is determined according to objective criteria, i.e. the understanding of the community (Živanović, 1927: 34). As a rule, the offensive character of a statement does not depend on its truthfulness or untruthfulness (Trešnjev, 2016: 59).

The criminal offense of insult can only be committed with intent, which, inter alia, must include the desire for the statement of offensive content to be known by the targeted person. Thus, if such a statement is entered in a personal diary and revealed by coincidence by another person, against the will of the person who entered the statement, it will not constitute a criminal offense of insult, since there is no intent for the insult to be known by another (Stojanović, 2012:508). The intent to disparage does not have to be part of the perpetrator's intent.

\section{LEGAL REGULATION OF THE CRIMINAL OFFENSE OF INSULT}

The criminal act of insult is regulated in Article 170 of the Criminal Code, which envisages the qualifying form of this criminal offense (items 1 and 2), its privileged form (item 3) and a special basis for excluding the illegality of the undertaken actions (item 4).

The act of committing the criminal offense of insult is determined by the consequent disposition. Hence, from the normative aspect, the criminal offense of insult is considered to have been committed if any activity suitable to cause the consequence of this criminal offense has been undertaken (Ćorović, Šemović, 2012: 99).

The qualifying circumstance of the basic form of criminal act is connected to the means and the manner of conduct. Thus, Article 170 (items 1 and 2) reads:

(1) Whoever insults another person shall be punished by a fine ranging from twenty to one hundred daily amounts, or a fine ranging from 40,000 to 200,000 RSD.

(2) If the criminal offense of insult was committed through press, radio, television or other media, or at a public gathering, the offender shall be punished by a fine ranging from eighty to two hundred forty daily amounts, or a fine ranging for 150,000 to 450,000 RSD.

\footnotetext{
${ }^{2}$ For example. Pulling hair, slapping, spraying, pushing, hitting another person, which does not result in inflicting bodily injuries, etc
} 
In theoretical considerations and court practice, there are doubts regarding the conceptual determination of the qualifying form of this offense committed at a public gathering. Even though the prevailing view over the years has been that the essential features of this form of criminal offense of insult would be fulfilled during the gathering of persons whose number and identity have not been determined in advance, which was in accordance with former legal solutions, the problem arouse by introducing the Public Assembly $\mathrm{Act}^{3}$. Article 3 of this Act defines public assembly as "gathering of more than 20 people for the purpose of expressing, accomplishing and promoting state, political, social and national beliefs and goals, other freedoms and rights in a democratic society". This definition of public gathering is in direct contradiction with former understanding in terms of the requirement of having an indefinite number of persons present at the gathering (Džinić, 1993: 2016).

As envisaged in Article 170 (item 2) of the Criminal Code, the privileged form of criminal offense of insult exist in the following circumstances:

(3) if the insulted person responds to an insult, the court may punish one or both parties, or exonerate one or both of them.

In this case, the privileged circumstance is not related to the conduct of the perpetrator, given the fact that the action he has undertaken is in accordance with the basic form of criminal offence of insult. It refers to the specific position of the perpetrator who will simultaneously have the position of both the accused and the private prosecutor in criminal proceedings. In this case, the legislator gives complete freedom to the court in terms of determining the scope of criminal sanction against the perpetrators. Filing a counterclaim is not a requirement for ensuring that the elements from Art. 170 (item 3) are fulfilled; it is sufficient to prove that the insulted person responded (Stojanović, Perić, 2006: 87). This theoretical explanation is debatable from the aspect of respect for the principles of legal certainty and legality in criminal law.

Article 170 (item 4) of the Criminal Code envisages the special ground for excluding the illegality of the undertaken actions. Thus Article 170 (item 4) states:

(4) There shall be no punishment for the perpetrator of criminal offences specified in paragraphs 1 through 3 of this Article if the statement is given within the framework of serious critique in a scientific, literary or art work, in discharge of official duties, journalist tasks, political activity, in defence of a right or justifiable interests, if it is evident from the manner of expression or other circumstances that there was no intent to disparage.

The justification of the legal provisions in Art. 170 (item 4) of the Criminal Code is related to the nature of offensive acts. While the statement or conduct in the basic form of the criminal offense of insult is required to be derogatory, the utterance and conduct of the perpetrator who is subject to the provision in Article 170 (item 4) has the character of criticism, as a social means of condemning inappropriate actions or behaviour. The goal of such criticism is not to disparage, underestimate or humiliate one's personality, but to point out to the mistakes and shortcomings in one's conduct and activities with the aim of overcoming them. In that case, the criticism must be serious, justified and within the limits of decency (Jovanović, 1983: 250). If an insult is aimed at a public figure, the fulfilment of the requisite conditions is interpreted with even more flexibility, given the fact that public figures must

${ }^{3}$ Public Assembly Act, Official gazette of RS, no. 6/2016 
show a greater degree of tolerance towards criticism in the media ${ }^{4}$ and considering that protection of honour and reputation cannot enjoy stronger legal protection than freedom of expression guaranteed by Article 10 of the European Convention for the Protection of Human Rights and Fundamental Freedoms. ${ }^{5}$

In case the statement is given within the framework of serious criticism in the course of performing official duty, journalistic task or political activity, the fulfilment of conditions provided in Article 170 (item 4) of the Criminal Code is assessed from the aspect of the nature of the activity within which the statement was given; thus, the fulfilment of the objective condition for excluding illegality may easily be determined. When it comes to a statement given on a scientific, literary or artistic work, the disputable question is whether the offensive statement may contain characteristics of scientific, literary or artistic works. In that case, there is a need for a comprehensive assessment of all the circumstances of the undertaken activity (Džinić, 1993:308).

The illegality of the act of committing the criminal offense of insult is excluded even if the perpetrator's statement was given in defence of some rights or protection of justified interests, which will be the subject matter of special consideration in this scientific article.

\section{ASSUMPTIONS FOR EXCLUDING THE ILLEGALITY OF AN INSULTING STATEMENT GIVEN IN DEFENCE OF A RIGHT OR PROTECTION OF LEGITIMATE INTERESTS}

Articles $18-21$ of the Criminal Code provide general legal grounds for exclusion of illegality of any criminal offense. The criminal offense of insult is among the rare criminal offence whose normative framework contains a special ground for excluding illegality.

The criminal offense of insult will not exist even if the requirements for the basic form of this criminal offense has been met, in case of cumulative fulfilment of the objective and subjective condition prescribed by Article 170 (4) of the Criminal Code (Stojanović, 2012: 507).

\subsection{Objective conditions for excluding the illegality of an offensive statement}

In addition to the aforesaid circumstances, the objective condition for excluding the illegality of the undertaken actions, envisaged in Art. 170 (4) of the Criminal Code, is fulfilled if the statement is given in defence of a right or protection of legitimate interests.

Such a statement refers to the action of natural persons who give statements of offensive content in order to defend themselves from an attack including elements of provocation (induced affective reaction) (Jovanović, 1983: 250). In legal theory and judicial practice, there is a undivided view that the objective requirement for the exclusion of illegality is met if the statement of a person is made in the course of proceedings in which a decision is made on his right or protected interest. ${ }^{6}$ In that case, it is necessary to determine the link

\footnotetext{
${ }^{4}$ Judgement of the Supreme Court of Cassation Kzz.no. 502/2019, dated 22.05.2019

${ }^{5}$ Act on the ratification of the ECHR, Official Journal of Serbia and Montenegro -International agreements, no. 9/2003, 5/2005, 7/2005, and Official Gazette of RS- International agreements, no. 12/2010 and 10/2015.

${ }^{6}$ In a child custody proceeding before the Social Welfare Centre, the statement of one of the parents on psychological status and religious beliefs of the other parent that negatively affect the child's mental development represents a value judgment towards the private prosecutor and not an insulting statement (Judgment of the District Court in Belgrade Kž.no. 153/2004). The defendant's objection to the private prosecutor's testimony in the course of criminal proceedings, which includes the utterance "its a lie", does not constitute disparagement , but the objection to the private prosecutor's testimony (Judgment of the District Court in Belgrade Kž.no. 440/2009)
} 
between the given statement and the right or interest that is protected by uttering offensive words. If an insulting statement is given regardless of the need to protect rights or interests, it will not be considered that the objective condition of excluding illegality has been fulfilled, notwithstanding the fact that it was made in the course of court proceedings. However, if an insulting statement was aimed at protecting a right or legitimate interest, the condition from Article 170 (4) of the Criminal Code will be considered fulfilled. Whether the statement of an offensive nature is related to the protection of rights or legitimate interests during the proceedings (or not) is a factual issue which is decided by the court in each specific case. As noted, it will be considered as protection of legitimate interest if the insulting speech sought to protect a prevailing interest which supersedes the one of protecting the honour and the reputation of another person (Džinić, 1993: 317).

The nature of proceedings for the protection of a right or justified interest is irrelevant from the standpoint of assessing the fulfilment of the objective condition for excluding illegality. It may be a criminal, a civil, or a non-judicial proceeding where individual rights and interests are the subject matter of decision-making processes.

There is a question of fulfilment of the objective condition for the exclusion of illegality if the statement is not given in the course of the proceeding where individual rights and the interests are being decided upon. In practice, there are no such cases; thus, this question has not been the subject of special consideration in legal theory. It is indisputable that there are no legal restrictions for applying the institute from Article 170 (item 4) of the Criminal Code. In that case, it is necessary to prove what right or legitimate interest is protected by the offensive statement and in what way. ${ }^{7}$

The legislator does not limit the implementation of Article 170 (item 4) of the Criminal Code to the need to protect one's own rights and interests. The objective condition will be fulfilled even if the statement was given in order to protect the rights or legitimate interest of another person. Even though this is a problematic solution, the courts should act in accordance with the legal provisions and enable the implementation of this Article, even in such a case.

Having in mind the cited legal provisions, the author believes that the dispositive of the indictment and court decision should include a mandatory designation and specification of the rights or legitimate interests protected by the offensive statement, which would be the basic precondition for further assessment of fulfilment of the requisite conditions ${ }^{8}$. Yet, as judicial practice does not support that kind of stance, the issue is practically not considered.

\subsection{Subjective conditions for excluding the illegality of an offensive statement}

In addition to ensuring the fulfilment of the objective condition for exoneration of the perpetrator of the criminal offense of insult uttered in defence of a right or protection of a legitimate interest by applying Article 170 (item 4) of the Criminal Code, the court has to determine whether the specific manner of expression or other circumstances in the case at issue includes a statement that was not given with the intent of disparaging another.

While the court assesses the connection of an insulting statement with the protection of rights or interests on the basis of the objective criteria, mainly linking it to the initiated proceeding on personal rights and interests, court has a huge discretionary authority in assessing the fulfilment of the subjective condition.

\footnotetext{
${ }^{7}$ E.g.: in a dispute between neighbours on the possible occupation of a portion of a plot, the right of way, etc.

${ }^{8}$ The same legal position is taken with regard to the obligation of specifying the rights or interests in case of the commission of the criminal offense of vigilantism (arbitrary assumption of right or authority) from Article $330 \mathrm{CC}$.
} 
Apart from the perpetrator's intent to make an insulting statement and the wish to communicate it to the targeted person, the court also has to determine the existence and the intention to disparage. In order to determine the fulfilment of this condition, the court has to take into consideration all the circumstances of the specific event: the history of the participants' relationship, the arguments that preceded the event, their subsequent communication, how the person who made an insult talked about the insulted person later, etc. ${ }^{9}$

If the collected evidence shows that the insult is an arbitrary personal attack aimed at undermining the private life of the targeted person, regardless of its connection to the proceeding in which the rights and the interests of the person in question are being decided on, it will be considered that the insult was given with the intention to disparage, which meets the criteria of the criminal offense of insult. ${ }^{10}$ Moreover, it cannot be seen as fulfilment of the subjective condition if the speech of offensive content was not preceded by an argument between the participants, if one cannot determine from other communication between the participants that the offensive statement was given in order to protect individual rights and interests, and if the intensity of the statement exceeds the intensity necessary for protection of rights and interests.

On the other hand, as the entire communication between the participants is aimed at exercising certain rights and justified interests, both before and after the critical event, this fact indicates the possibility of applying Article 170 (item 4) of the Criminal Code. If the content of an insulting statement is of such nature that it tends to counter the claim of the other person, this clearly indicates the need to protect the rights or justified interest. Thus, if the aforesaid conditions are met, the statement shall not be considered given with intent to disparage, regardless of its indisputably offensive character; in such a case, the perpetrator shall be exonerated from the accusation (charges).

However, even if it is indisputably established that the intent to utter offensive words is aimed at protecting individual rights and interests, the author believes that the criminal act of insult exists in case when the offense is of such intensity that it exceeds the limits of tolerance required for the protection of individual rights and interests, particularly given the fact that the intensity of the uttered words speaks in favour of the intent to disparage.

\section{INTENT TO DISPARAGE AS AN OBLIGATORY ELEMENT OF THE CRIMINAL OFFENSE OF INSULT}

The notion of a criminal offense is defined in the provisions of Article 14 of the Criminal Code. The provided definition points to the general elements that are inseparable parts of every criminal offence: the criminal offence must be prescribed by the law, unlawful, and culpable (committed with the guilty mind). The unlawfulness of an act results from its conceptual definition in the law, and it must be explicitly included in the operative part of the judgment only in exceptional cases, as an element of the nature of the specific crime. On the other hand, culpability represents a subjective element of the crime, which entails three distinctive elements: guilt, sanity, and awareness of the illicit nature of the committed crime), whereby all three elements must be included in the indictment and the operative part of the judgment.

\footnotetext{
${ }^{9}$ See: Majić, Miša (2015). Krivično delo uvrede (Criminal offence of insult), Blog Sudije Majica (8.7. 2015)

${ }^{10}$ Judgment of the Supreme Court of Cassation Kzz.no. 528/2019, dated 30.05.2019
} 
In addition to establishing the presence of the aforesaid general elements of crime, it is necessary to determine the existence of the specific elements that are characteristic for each individual criminal offense, and contained in a separate part of the Criminal Code.

When it comes to the criminal offense of insult, by citing Article 170 (item 1) of the Criminal Code, one specifies that the legal feature of the criminal offense in question is offensive utterance or conduct. Therefore, in order for the court to find the perpetrator of the criminal offense of insult guilty, the dispositive of the private criminal complaint (for prosecution of the offender) shall clearly state the general elements that must be contained in each criminal offense, as well as the special element of the criminal offense of insult (offensive content)..

The application of legal grounds that exclude illegality of the offensive statement requires the fulfilment of additional conditions envisaged in the provisions of Article 170 (item 4) of the Criminal Code. The fulfilment of these conditions is assessed from the theoretical perspective, and it depends on the court's assessment in each specific case. These conditions are not considered as necessary elements of the private criminal complaint since they are not explicitly contained in the corpus delicti of the criminal offense of insult. ${ }^{11}$

For years, the legal theory and judicial practice have been confronting the dilemma whether the intent to disparage is an important subjective element of the criminal offense of insult and, as such, whether it must be explicitly included in the operative part of the private criminal complaint filed by a private prosecutor and in the court judgment.

Formally speaking, the intent to disparage is not a legal feature of the criminal offense (Stojanović, 2012: 508); thus, it is not a legal feature of the criminal offense of insult uttered in defence of individual rights or protection of legitimate interests. Consequently, the court is not obliged to include it in the judgment as a mandatory element, nor is the prosecutor obliged to designate it in the indictment. ${ }^{12}$

Contrary to the formal stance confirmed in the cited judgement, the judicial practice is increasingly dominated by the legal stance on the necessity of stating the intent to disparage as an obligatory element that should be included in every private criminal complaint and judgement if the case involves offensive speech given in defence of a personal right or protection of justified interests. In a number of judgments ${ }^{13}$, the Supreme Court of Cassation took the stand that the intent to disparage, although not explicitly contained in the corpus delicti of the criminal offense of insult, is actually part of this criminal offence because, without it, it is impossible to determine the fulfilment of conditions for the application of the provisions envisaged in Article 170 (item 4) of the Criminal Code. Therefore, the private prosecutor is obliged to indicate the intent to disparage as an obligatory element in the operative part of the private criminal complaint if the offensive statement is given in defence of rights or protection of legitimate interests. If he fails to do so, the court is obliged to exonerate the perpetrator from liability because the subject matter of the private criminal complaint is not a criminal offence, considering the failure to specify all elements that a criminal act must contain under the law. Hence, without the interference of a private prosecutor, the court cannot enter the intent to disparage (as an essential element of the criminal offense) in the judgment because it would exceed the scope of the criminal complaint.

\footnotetext{
${ }^{11}$ Judgment of the Supreme Court of Cassation Kzz.no. 23/2019, dated 30.01.2019

${ }^{12}$ Such legal stance was taken in the judgement of the Supreme Court of Cassation Kzz no. 1257/19 of 28.11.2019.

${ }^{13}$ Judgments of the Supreme Court of Cassation in cases: Kzz. no. 394/2014 of 22.05.2014., Kzz. no. 1228/2017 of 05.12.2017. and Kzz. no. 23/2019 of 30.01.2019
} 
The contradictory standpoints observable in the decisions of the Supreme Court of Cassation generates legal uncertainty in terms of the (non)binding inclusion of intent to disparage as an element of the corpus delicti of the criminal offence of insult. It is unacceptable that the Supreme Court of Cassation, as the court of the highest instance, takes conflicting legal standpoints on the same legal issue (during the same adjudication period).

Formally speaking, it is indisputable that the intent to disparage does not constitute a legal feature of the criminal offense of insult. For that reason, the author of this paper considers that the legal stance on the obligatory stipulation of the intent to disparage as a feature of this criminal offence has no legal justification. Thus, it was inappropriate to interpret the provisions of Article 170 (item 4) of the Criminal Code in the sense of mandatory inclusion of the intent to disparage as a subjective element of the corpus delicti of the criminal offence of insult. The legislator clearly and unambiguously prescribes the necessary elements that a private criminal complaint and court decision must contain; therefore, any interpretation of mandatory elements of criminal act, outside the legal framework, is simply not justified and undermines the legal certainty. In such a case, legal solutions are rendered meaningless and subjugated to the judicial practice.

\section{CONCLUSION}

The discussion presented in this scientific article indicates the need for a detailed analysis of the prerequisites for the application of the legal grounds for excluding the illegality of offensive statement, prescribed in provisions of Article 170 (item 4) of the Serbian Criminal Code. Although this is one of the grounds for exonerating the perpetrator from criminal liability for the committed criminal offence, the existing theoretical considerations basically retell the legal text, without providing further clarification and more precise interpretation of these legal provisions. It has ultimately contributed to rather diverse and uneven judicial practice.

By underscoring the general characteristics of the legal grounds whose application excludes illegality of the criminal offense, the author points out to the importance and the role of this legal institute in substantive criminal law. By analysing the basic features of the criminal offense of insult from the theoretical and normative perspective, the author calls attention to the social values that are protected by incriminating offensive conduct as a special criminal offense, and elaborates on the legal regulation of this criminal offense in terms of determining the object of protection, the actual forms of perpetration of this offence and manifestations of the offensive conduct, and the conceptual definition of the subjective element of the criminal offense of insult. This theoretical framework has served as a basis for understanding the intention of the legislator to provide special grounds for excluding the illegality of offensive statement. The author refers to the preconditions for the application of the legal institute stipulated in Article 170 (item 4) of the Criminal Code and presents the optimal manner of their practical application by relying on their theoretical analysis. In particular, the analysis focuses on the intent to disparage, as a special subjective element of crime, as well as on the dilemma present in judicial practice regarding the need to introduce it as an obligatory element of the criminal offense of insult. The analysis of the judgments of the Supreme Court of Cassation often shows diametrically opposite approach to the same legal issue or to the interpretation of criminal law provisions that are crucial in rendering the decision on excluding the illegality of offensive statement. Such an approach largely contributes to legal uncertainty. The author believes that legal theory has not recognized the significance of providing adequate theoretical explanation on the 
special legal grounds for decriminalization of offensive behaviour, which has generated ample dilemmas and resulted in rendering contradictory court decisions.

In that regard, publishing scientific articles, professional papers, expert opinions and comments, collections of court decisions in the field covered by this scientific article, and organizing seminars and consultations judicial professionals and other governmental authorities is of great importance for establishing uniform and consistent court practice in this field, as well as for presenting theoretical explanations that will greatly facilitate correct interpretation of criminal law provisions envisaged in Article 170 (item 4) of the Serbian Criminal Code, whose application may be a significant factor in establishing criminal liability for the criminal offense of insult and assessing whether the essential requirements for have been met.

\section{REFERENCES}

Ćorović, E., Šemović, A., (2012). Uvreda i kleveta u krivičnom zakonodavstvu pojedinih evropskih zemalja (Insult and Defamation in criminal legislation of some European countries), in: Evropsko zakonodavstvo, Đ. Dimitrijević (ed), Institut za međunarodnu politiku i ekonomiju, br. 42, 2012, p. 93-117, Beograd.

Džinić, S., (1993). Krivično delo uvrede, doktorska disertacija (Criminal Offence of Insult, doctoral dissertation), Pravni fakultet, Univerzitet u Beogradu, Beograd.

Ignjatović, A., (2007). Krivično pravo - posebni deo (Criminal Law - special part), Privredna akademija, Novi Sad,

Jovanović, Lj., (1983). Krivično pravo - posebni deo (Criminal Law - special part), Univerzitetska biblioteka "Svetozar Marković", Univerzitet u Beogradu.

Jovanović, Lj., Đurđić, V., Jovašević, D., (2000). Krivično pravo-posebni deo (Criminal Law - special part), Pravni fakultet, Univerzitet u Nišu, Niš.

Jovašević, D., (2017). Krivično pravo - posebni deo (Criminal Law - special part), Dossier, Beograd.

Majić, M., (2015). Krivično delo uvrede (Criminal offence of insult), Blog Sudije Majica (posted 8.7. 2015); http://misamajic.com/Pitanje/krivicno-delo-uvrede/; assessed 14 July 2020.

Stojanović, Z., Perić, O., (2006). Krivično pravo-posebni deo (Criminal Law - special part), Pravna knjiga, Beograd.

Stojanović, Z., (2012). Komentar Krivičnog zakonika, četvrto izmenjeno izdanje (Commentary on the Criminal Code, $4^{\text {th }}$ revised edition), JP Službeni glasnik, Beograd.

Trešnjev, A., (2016). Zbirka sudskih odluka u krivičnopravnoj materiji (Collection of court decisions in criminal matters), JP Službeni glasnik, Beograd.

Živanović, T., (1927). O uvredi i kleveti (On Insult and Slender), Izdavačko i knjižarsko preduzeće Geca Kon, Beograd

\section{Legislation}

Кривични законик Републике Србије (Criminal Code of the Republic of Serbia), Службени гласник PC, бр. 85/2005, 88/2005, 107/2005, 72/2009, 111/2009, 121/2012, 104/2013, 108/2014, 94/2016, 35/2019

Закон о јавном окупљању (Public Assembly Act), Службени гласник РC, бр. 6/2016

Закон о ратификацији Европске конвенције за заштиту људских права и основних слобода (Act on the ratification of the European Convention for the Protection of Human Rights and Fundamental Freedom), Службени лист СЦГ-Међународни уговори, бр. 9/2003, 5/2005, 7/2005, и Службени гласник РСМеђународни уговори, бр. 12/2010 и 10/2015

\section{Judicial practice (case law)}

Пресуда Врховног касационог суда (Judgement of the Supreme Court of Cassation) Kzz.br. 394/2014 od 22.05.2014.

Пресуда Врховног касационог суда (Judgement of the Supreme Court of Cassation) Kzz.br.. 1228/2017 od 05.12.2017.

Пресуда Врховног касационог суда (Judgement of the Supreme Court of Cassation) Kzz. br.. 23/2019 od 30.01.2019.

Пресуда Врховног касационог суда (Judgement of the Supreme Court of Cassation) Kzz. br. 502/2019 od 22.05.2019.

Пресуда Врховног касационог суда (Judgement of the Supreme Court of Cassation) Kzz. br.. 1257/19 od 28.11.2019. 


\section{ISKLJUČENJE PROTIVPRAVNOSTI UVREDLJIVOG IZLAGANJA DATOG U ODBRANI NEKOG PRAVA ILI ZAŠTITI OPRAVDANIH INTERESA}

Predmet ovog naučnog članka predstavlja analiza osnovnih obeležja i elemenata krivičnog dela uvrede sa teorijskog i normativnog aspekta sa posebnim osvrtom na analizu uslova primene posebnog osnova isključenja protivpravnosti uvredljivog izlaganja, propisanog odredbama čl. 170 st. 4 Krivičnog zakonika. U tom smislu, autor kritičkom analizom nacionalne krivičnopravne regulative i kraćim osvrtom na praksu nacionalnih sudova ukazuje na kontradiktornost usvojenih pravnih stavova prilikom tumačenja spornih odredbi, čime se ističe važnost ujednačavanja sudske prakse u navedenoj oblasti. Pravilnim $i$ potpunim sagledavanjem krivičnog dela uvrede, a posebno osnova koji isključuje protivpravnost preduzetih radnji, propisanog odredbama čl. 170 st. 4 Krivičnog zakonika, ukazuje se na neophodnost precizne interpretacije navedenih krivičnopravnih odredaba, obzirom da neadekvatno postupanje pravosudnih organa u tom smislu povlači sa sobom mogućnost osude učinioca krivičnog dela uvrede, iako uslova za to, shodno pozitivnim zakonskim propisima, nema.

Ključne reči: uvreda, normativna regulativa, pretpostavke isključenja protivpravnosti, zaštita prava $i$ opravdanih interesa, namera omalovažavanja 